\title{
PENGARUH VARIASI UKURAN AGREGAT TERHADAP KARAKTERISTIK BETON DENGAN CAMPURAN ABU SEKAM PADI
}

\author{
Dilla Zulhijah, Sri Handani dan Sri Mulyadi \\ Jurusan Fisika FMIPA Univeritas Andalas \\ e-mail:dillazulhijah@yahoo.com
}

\begin{abstract}
ABSTRAK
Telah dilakukan penelitian tentang pengaruh variasi ukuran agregat kasar 9,6-12,5 mm, 12,5-19 mm dan 19- 25,4 mm terhadap karakteristik beton dengan campuran abu sekam padi $10 \%$. Semen yang digunakan yaitu Ordinary Portland Cement (OPC). Karakterisasi yang dilakukan meliputi pengujian kuat tekan, kuat tarik, porositas dan daya serap air dengan mutu beton K350. Hasil optimal untuk kuat tekan diperoleh pada ukuran agregat 9,6 - 12,5 mm sebesar $487 \mathrm{~kg} / \mathrm{cm}^{2}$, sedangkan untuk kuat tarik diperoleh pada ukuran agregat $12,5-19 \mathrm{~mm}$ sebesar $35 \mathrm{~kg} / \mathrm{cm}^{2}$. Porositas dan daya serap air optimal diperoleh pada ukuran agregat 9,6 -12,5 mm masing - masing sebesar $1,9 \%$.
\end{abstract}

Kata kunci : kuat tekan, kuat tarik, porositas, daya serap air, abu sekam padi

\section{PENDAHULUAN}

Dewasa ini, pembangunan perumahan, gedung perkantoran dan pabrik - pabrik industri semakin banyak memerlukan ketersediaan bahan baku yang berkualitas dan murah. . Beton merupakan salah satu bahan konstruksi yang banyak dipergunakan dalam struktur bangunan modern, namun bahan penyusun yang digunakan semakin mahal dan terbatas.

Beton adalah suatu komposit dari beberapa bahan batu - batuan yang direkatkan oleh bahan - ikat. Beton dibentuk dari agregat campuran (halus dan kasar) dan ditambah dengan pasta semen. Singkatnya dapat dikatakan pasta semen mengikat pasir dan bahan bahan agregat lain (batu kerikil, basalt dan sebagainya). Rongga di antara bahan - bahan kasar diisi oleh bahan - bahan halus (Sagel dkk., 1993).

Agrerat menempati $70 \%-75 \%$ dari total volume beton maka kualitas agrerat sangat berpengaruh terhadap kualitas beton. Pada dasarnya agregat kasar memegang peranan penting untuk menentukan mutu beton kinerja tinggi. Apabila agregat mempunyai ukuran butiran yang lebih halus dan dengan ukuran yang bervariasi, maka volume pori beton menjadi kecil. Hal ini disebabkan butiran yang lebih kecil akan mengisi pori antara butiran yang lebih besar, sehingga pori-porinya menjadi sedikit dan beton memiliki kemampatan yang tinggi.

Sesuai dengan perkembangan teknologi untuk memperbaiki sifat - sifat beton maka beton diberi bahan tambahan. Bahan tambahan itu seperti limbah buangan serat ijuk, sabut kelapa, serat nilon, abu sekam padi, ampas tebu, sisa kayu, limbah gergajian, abu cangkang sawit, abu terbang (fly ash), mikrosilika (silica fume), cangkang kemiri dan lain-lain (Mulyono, 2004).

Padi merupakan produk utama pertanian di negara-negara agraris, termasuk Indonesia. Karena pemanfaatan sekam padi yang masih relatif kecil, sekam padi biasanya dibuang dan dibakar. Pengelolaan sekam padi dengan cara seperti ini kurang efektif karena tidak menghasilkan material baru yang bernilai ekonomis. 
Manfaat sekam padi saat ini telah dikembangkan pula sebagai bahan baku untuk menghasilkan abu pozzolan yang dikenal di dunia sebagai abu sekam padi (rice husk ask). Abu sekam padi yang dihasilkan dari pembakaran sekam padi pada suhu $400{ }^{\circ} \mathrm{C}-$ $500{ }^{\circ} \mathrm{C}$ akan menjadi silika amorphous dan pada suhu lebih besar dari $1000{ }^{\circ} \mathrm{C}$ akan menjadi silika kristalin (Shinohara dan Kohyama, 2004).

\section{METODE}

Alat yang digunakan pada penelitian ini yaitu Mesin kuat tekan ( Universal testing machine Co.Id Tokyo Japan No.6609), neraca, gelas ukur, cetakan silinder, kawat penggantung, scrap, ayakan dan oven. Bahan yang digunakan yaitu semen, agregat (9,6 $12,5 \mathrm{~mm} ; 12,5$ - $19 \mathrm{~mm}$; (19 - 25,4 mm), air dan abu sekam padi.

\section{Persiapan material}

Bahan yang dipersiapkan adalah abu sekam padi. Untuk bahan utama beton yaitu semen, agregat halus, agregat kasar dan air. Agrerat kasar yang digunakan pada penelitian ini berupa batu pecah ukuran 9,5-12,5 mm, 12,5-19mm, dan $19-25,4 \mathrm{~mm}$. Masing masing bahan dicuci untuk mengurangi kadar organik dan kadar lumpurnya kemudian dilakukan penyaringan agregat halus lalu dicuci dan dibiarkan sampai kondisi jenuh kering permukaannya konstan.

Untuk material semen tidak dilakukan pengujian karena semen yang digunakan telah memenuhi persyaratan teknis yang sesuai dengan peraturan SNI 15-2049-2004. Air yang digunakan adalah air yang ada di Laboratorium Aplikasi Semen dan Beton PT. Igasar. Pengujian air yang dilakukan adalah pengecekan $\mathrm{pH}$ air. Pengecekan $\mathrm{pH}$ air dilakukan untuk mengetahui seberapa besar tingkat keasaman atau kebasaan air sehingga tidak merusak beton.

\section{Pengujian Kuat Tekan}

Sebelum dilakukan uji kuat tekan, benda uji yang akan diuji sesuai umur diambil dari bak perendaman dan dibiarkan sampai permukaannya kering dan ditimbang massanya. Benda uji diberi mortar belerang yang telah dipanaskan (capping) pada bagian yang akan ditekan dan dibiarkan beberapa saat sampai mengeras. Benda uji diletakkan pada mesin kuat tekan dengan sisi yang di-capping. Pembebanan dilakukan sampai benda uji runtuh dan dicatat besarnya beban tertinggi yang ditunjukkan oleh jarum manometer mesin kuat tekan. Setelah mencapai beban runtuh, kekuatan tekan dihentikan dan penutup tekanan dibuka hingga piston tekan akan naik. Kuat tekan dihitung menggunakan persamaan (1)

$$
f c=\frac{P}{A}
$$

dengan

$$
\begin{aligned}
& f_{C}: \text { kuat tekan }\left(\mathrm{kg} / \mathrm{cm}^{2}\right) \\
& P: \text { beban yang diberikan }(\mathrm{kg}) \\
& A: \text { luas penampang yang terkena penekanan gaya }\left(\mathrm{cm}^{2}\right)
\end{aligned}
$$

\section{Pengujian Kuat Tarik (Tensile Strength)}

Langkah - langkah pengujian dan mesin yang digunakan sama dengan pengujian kuat tekan tetapi benda uji diletakkan pada mesin kuat tekan dengan posisi rebah. Benda uji tidak di- capping tetapi ditambahkan dengan batangan agar dapat membagi beban merata pada sepanjang silinder. Dari kekuatan maksimal yang diberikan pada benda uji, kekuatan tarik dapat dihitung dengan menggunakan persamaan (2) 


$$
f_{c}=\frac{2 P}{\pi d d}
$$

dengan

$$
\begin{aligned}
& f^{\prime} c: \text { kuat tarik belah }\left(\mathrm{kg} / \mathrm{cm}^{2}\right) \\
& P \text { : beban yang diberikan }(\mathrm{kg}) \\
& l: \text { panjang silinder }(\mathrm{cm}) \\
& d \quad: \text { diameter silinder }(\mathrm{cm})
\end{aligned}
$$

\section{Pengujian Penyerapan Air (Water Absorbtion)}

Sampel yang telah direndam dikeluarkan dari bak perendaman kemudian permukaannya dikeringkan dan ditimbang massanya sebagai massa kering setelah direndam. Sampel digantung dengan kawat penggantung, kemudian ditimbang massanya di dalam wadah berisi air (kurangkan dengan massa benang penggantung), ditimbang massanya sebagai massa dalam air.Sampel yang basah tadi dipanaskan di dalam oven dengan temperatur $100^{\circ} \mathrm{C}$ selama 24 jam, kemudian ditimbang massanya sebagai massa kering (A). Besarnya penyerapan air ini dapat dihitung dengan persamaan 3.

$$
W A=\frac{C-A}{A} \times 100 \%
$$

dengan

$$
\begin{aligned}
& \text { WA : water absorption (\%) } \\
& C \text { : massa kering sampel setelah direndam (gram) } \\
& A \quad \text { : massa kering oven sampel (gram) }
\end{aligned}
$$

\section{Pengujian Porositas}

Sampel yang telah direndam dikeluarkan dari bak perendaman kemudian permukaannya dikeringkan dan ditimbang massanya sebagai massa kering setelah direndam. Sampel digantung dengan kawat penggantung, kemudian ditimbang massanya di dalam wadah berisi air (kurangkan dengan massa benang penggantung), ditimbang massanya sebagai massa dalam air. Sampel yang basah tadi dipanaskan di dalam oven dengan temperatur $100^{\circ} \mathrm{C}$ selama 24 jam, kemudian ditimbang massanya sebagai massa kering (A). Besarnya porositas ini dapat dihitung dengan persamaan 4.:

$$
P=\frac{C-A}{C-D} \times 100 \%
$$

dengan

$$
\begin{aligned}
& P: \text { porositas }(\%) \\
& C: \text { massa kering sampel setelah direndam (gr) } \\
& A: \text { massa kering oven sampel (gr) } \\
& D: \text { massa sampel digantung didalam air (gr) }
\end{aligned}
$$


3. HASIL DAN DISKUSI

Hasil pengujian untuk semen tipe I (Ordinary Portland Cement, OPC)

1. Kuat tekan

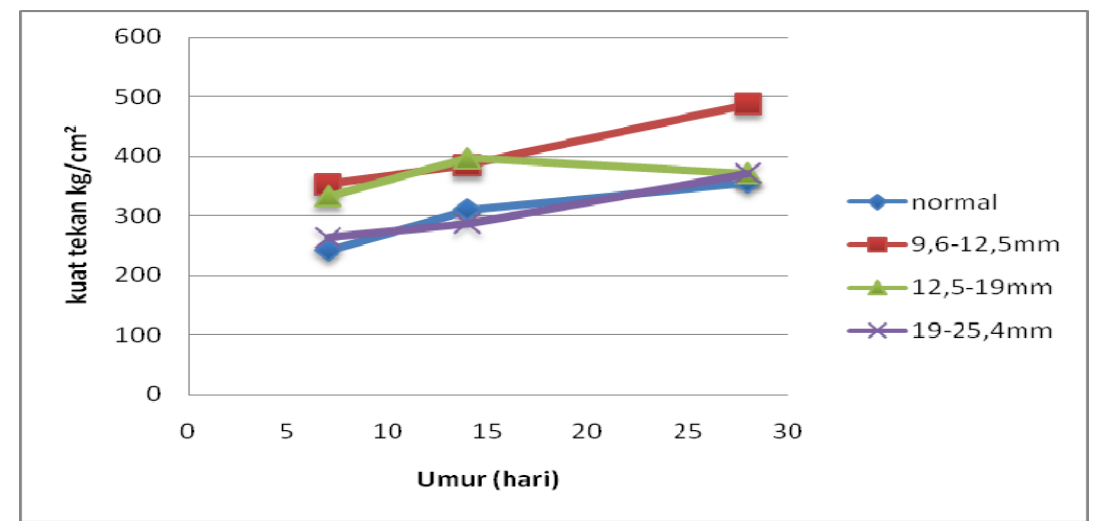

Gambar 1. Hasil uji kuat tekan

Dari Gambar 1, hasil penujian menunjukkan nilai kuat tekan beton normal lebih rendah dibandingkan beton variasi ukuran agregat 9,6-12,5 mm dengan campuran abu sekam padi. Pada umur 7 hari nilai kuat tekan beton diperoleh sebesar $242 \mathrm{~kg} / \mathrm{cm}^{2}$, umur 14 hari diperoleh sebesar $311 \mathrm{~kg} / \mathrm{cm}^{2}$ dan umur 28 hari sebesar $356 \mathrm{~kg} / \mathrm{cm}^{2}$. Sedangkan beton variasi ukuran agregat $9,6-12,5 \mathrm{~mm}$ pada umur 7 hari nilai kuat tekan beton diperoleh sebesar $353 \mathrm{~kg} / \mathrm{cm}^{2}$, umur 14 hari diperoleh sebesar $395 \mathrm{~kg} / \mathrm{cm}^{2}$ dan umur 28 hari sebesar $487 \mathrm{~kg} / \mathrm{cm}^{2}$. Peningkatan kekuatan beton dengan mencampurkan abu sekam padi disebabkan oleh semakin berkurangnya pori - pori yang terdapat pada beton. Pori - pori pada beton semakin berkurang karena diisi oleh serbuk - serbuk halus abu sekam padi yang mengakibatkan beton lebih padat. Selain itu, peningkatan beton dengan campuran abu sekam padi terjadi karena Silica oksida $\left(\mathrm{SiO}_{2}\right)$ yang terdapat dalam abu sekam padi akan bereaksi dengan $\mathrm{Ca}(\mathrm{OH})_{2}$ sehingga akan menjadi senyawa $\mathrm{CSH}$ gel, dimana senyawa CSH gel tersebut akan mengisi celah-celah yang lemah yaitu antara agregat dengan pasta semen sehingga akan memperkuat matrik beton.

\section{Kuat Tarik}

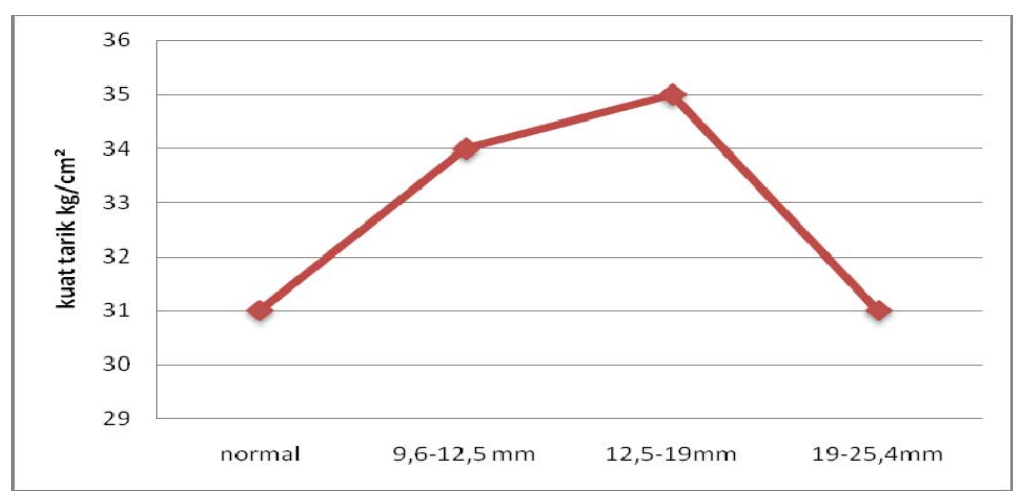

Gambar 2. Hasil uji kuat tarik

Dari Gambar 2, hasil pengujian menunjukkan nilai kuat tarik beton normal umur 28 hari sebesar $31 \mathrm{~kg} / \mathrm{cm} 2$, kuat tarik untuk variasi ukuran agregat 9,6-12,5 mm dengan campuran abu sekam padi diperoleh sebesar $34 \mathrm{~kg} / \mathrm{cm}^{2}$, ukuran agregat 12,5-19 mm diperoleh nilai kuat tarik sebesar $35 \mathrm{~kg} / \mathrm{cm}^{2}$ dan ukuran agregat 19- 25,4 mm diperoleh nilai kuat tarik sebesar $31 \mathrm{~kg} / \mathrm{cm}^{2}$. Namun pada agregat $12,5-19 \mathrm{~mm}$ terjadi kenaikan nilai kuat tarik. Hal itu terjadi karena komposisi dari campuran agregat dalam beton tidak 
sama karena dalam pembuatan benda uji tersebut dilakukan secara bersamaan sehingga penakaran untuk setiap benda ujinya kemungkinan ada yang kelebihan agregat.

3. Porositas

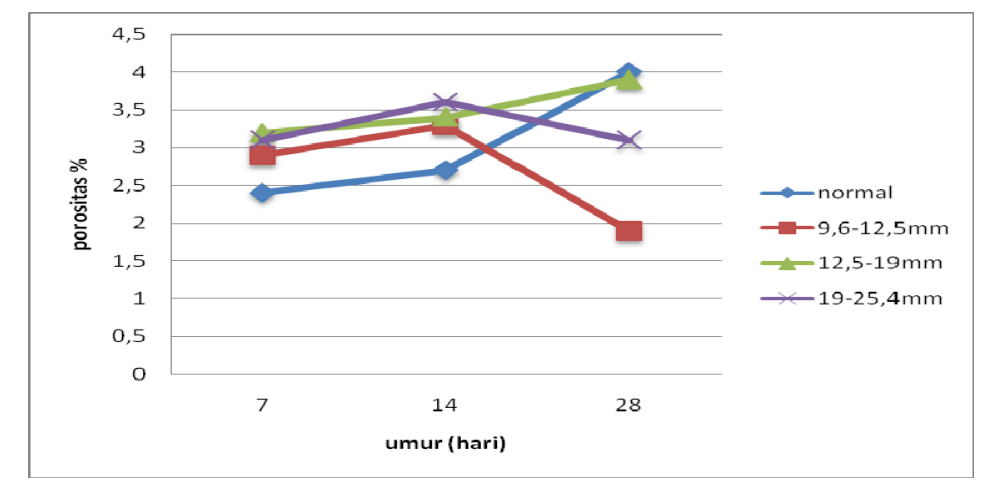

Gambar 3. Hasil pengujian porositas

Dari Gambar 3, hasil pengujian menunjukkan porositas untuk beton normal lebih besar dibandingkan beton variasi ukuran agregat 9,6 -12,5 $\mathrm{mm}$ dengan campuran abu sekam padi. Pada umur 7 hari porositas diperoleh sebesar 2,4\%, umur 14 hari diperoleh sebesar $2,7 \%$ dan umur 28 hari sebesar $4 \%$. Pada variasi ukuran agregat 9,6-12,5 mm juga terjadi peningkatan nilai porosiitas. Pada umur 7 hari nilai porositas diperoleh sebesar 2,9 $\%$, umur 14 hari diperoleh sebesar 3,3\%. Namun pada umur 28 hari terjadi penurunan porositas. Nilai porositas yang diperoleh pada umur 28 hari sebesar 1,9\%. Hal ini terjadi karena ketika beton norrnal berumur 28 hari beton mengalami pengeringan. Pada saat terjadi pengeringan beton memiliki rongga - rongga, tetapi pada beton campuran abu sekam padi rongga yang terdapat pada beton tersebut ditutupi oleh abu sekam padi sehingga nilai porositas beton campuran abu sekam padi dengan varasi ukuran agregat 9,6 $-12,5 \mathrm{~mm}$ lebih rendah dibandingkan dengan beton normal.

4. Daya serap air

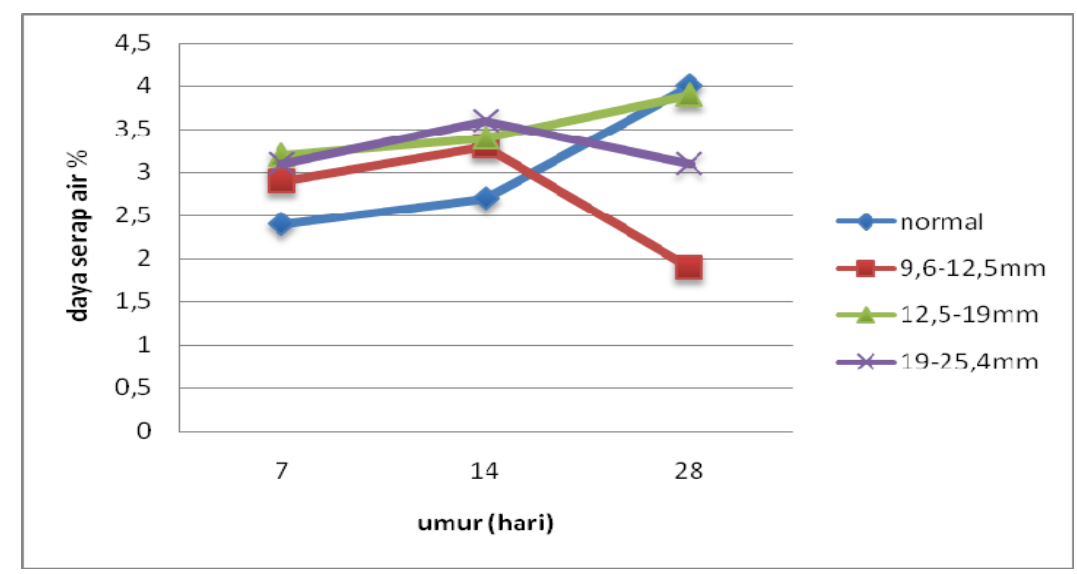

Gambar 4. Pengujian daya serap air

Dari Gambar 4, hasil pengujian menunjukkan nilai uji daya serap air untuk beton normal lebih besar dibandingkan dengan beton variasi ukuran agregat 9,6-12,5 $\mathrm{mm}$. Nilai daya serap air untuk beton normal pada umur 7 hari nilai uji porositas diperoleh sebesar 2,4\%, umur 14 hari diperoleh sebesar 2,7\% dan umur 28 hari sebesar $4 \%$. Pada variasi ukuran 
agregat 9,6 - 12,5 mm juga terjadi peningkatan nilai uji porosiitas. Pada umur 7 hari nilai uji daya serap air diperoleh sebesar 2,9\%, umur 14 hari diperoleh sebesar 3,3\%. Namun pada umur 28 hari terjadi penurunan nilai uji daya serap air. Nilai uji daya serap air yang diperoleh pada umur 28 hari sebesar 1,9\%. Hal ini terjadi karena abu sekam memiliki kandungan silika yang tinggi. Silika yang bercampur dengan semen dan air akan menghasilkan kalsium silikat hidrat (CSH) sekunder setelah proses hidrasi berlangsung. $\mathrm{CSH}$ sekunder ini akan mengurangi bahkan menutup rongga yang terbentuk pada komposit semen sehingga akan mengurangi permeabilitas air yang akan masuk ke agregat.

\section{KESIMPULAN}

Nilai kuat tekan yang diperoleh dari hasil penelitian sesuai dengan beton perencanaan $\mathrm{K}$ 350 sebesar $487 \mathrm{~kg} / \mathrm{cm}^{2}$ pada beton ukuran agregat 9,6-12,5. Hasil optimal porositas dan daya serap air diperoleh pada beton ukuran agregat 9,6-12,5 masing - masing sebesar 1,9 $\%$. Sedangkan kuat tarik optimal diperoleh pada beton ukuran agregat 12,5 - 19 sebesar $35 \mathrm{~kg} / \mathrm{cm}^{2}$.

\section{DAFTAR PUSTAKA}

1. Mulyono, T., 2005, Teknlogi Beton, Andi, Yogyakarta.

2. Sagel, R., Kole, P dan Gideon, H., 1993, Pedoman Pengerjaan Beton, Erlangga, Jakarta.

3. Shinohara, Y. and Kohyama, N., 2004, Quantitative Analysis of Tridymite and Cristobalite Crystallized in Rice Husk Ash by Heating, Industrial Health, 42: 277285. 